\title{
Students' Career Understanding and Career Decision Making Self-Efficacy in Junior High School
}

\author{
Khayatun Nufus Akhsania ${ }^{1 *}$, (D) Tentrem Basuki ${ }^{1}$, DYP Sugiharto ${ }^{1}$, \\ Muhammad Japar ${ }^{4}$ \\ Universitas Negeri Semarang, Indonesia ${ }^{1}$ \\ Universitas Muhamadiyah Magelang, Indonesia ${ }^{2}$ \\ Q khayatunakhsania@gmail.com*
}

Article Information:

Received January 25, 2020

Revised July 2, 2020

Accepted August 15, 2020

Keywords: career development; career understanding; CDSE-SF; junior high school

\begin{abstract}
This study aimed to determine students' career understanding on the career decision making self-efficacy of Junior High School students in Central Java Province. The study used qualitative method, comparative test for data analysis, and self-efficacy scale to collect the career decision making data of students who have and have not gained career understanding. In this way, Bandura's theory of self-efficacy was used as a framework theory, while cluster random sampling was employed to collect the study sample $(N=311)$. The data collection was done through a direct survey using 25 questions regarding career decision making self-efficacy (CDSE-SF) and career understanding questionnaire. Based on the data analysis, the researchers found significant differences in CDSE-SF results of students who have gained career understanding and not, including (1) Understanding of various alternative jobs $(t(311)=4.911, p<.000),(2)$ Information on the world of work requirements $(t(311)=4.602, p<.000)$, (3) Information on job vacancies $(\mathrm{t}(311)=4.111, \mathrm{p}<.000)$, and (4) Understanding of job qualifications $(t(311)=3.460, p<.001)$. These findings recommend the students to improve their career decision making using career guidance and counseling strategies in form of various alternative services, such as career counselling services, group guidance, classroom service, and even support from other parties.
\end{abstract}

\section{INTRODUCTION}

Education, for example, formal education is an important medium to improve human resources quality, help human grow and develop potential within, and provide future education for every individual (Depdiknas, 2003). This importance urges countries to assist their citizens by providing ideal education so that the national education goal, namely providing suitable curriculum and instructors for individual development in career specialization can be realized.

Career affects human life happiness as a whole. Therefore, the accuracy of career selection and decision making becomes a prominent point in the journey of human life. Career decision starts from adolescence period or at Junior High School level aged between 11-15 years. In this period, adolescents have been able to think abstractly and hypothetically, predict what may happen, and plan their future (Steinberg, 2014). Junior High School students' career maturity covers career insight and readiness, ability to describe various jobs, gain education and activities related to self-abilities (Kebudayaan, 2016). Career decision making is a significant developmental task which takes place at the end of adolescence and

How to cite:

E-ISSN:

Published by:
Akhsania, K., Basuki, T., Sugiharto, D., \& Japar, M. (2020). Students' Career Understanding and Career Decision Making Self-Efficacy in Junior High School. Islamic Guidance and Counseling Journal, 4(1). https://doi.org/10.25217/igcj.v4i1.950 2614-1566

Institut Agama Islam Ma'arif NU (IAIMNU) Metro Lampung 
early adulthood period. Accordingly, adolescents can perform such task if they can understand abilities (general intelligence, special talents, academic achievement, and work skills), vocational interest, and personal characteristics. However, not all of them can fulfil these requirements due to lack of motivation in career selection involvement, lack of selfunderstanding, lack of environmental understanding, and lack of knowledge about relationship between self and environment (Breeding, 2008).

Career decision making is strongly related to self-efficacy. According to Bandura (2010) self-efficacy is defined as one's assessment of his abilities to plan and carry out actions that lead to a particular goal. The term popularized by Bandura $(1969,1989)$ also refers to belief in one's abilities to manage and implement his actions to pursue goals. In other words, self-efficacy is self-assessment regarding competencies used to accomplish specific tasks. Career decision making belief or career self-efficacy is considered as a determinant factor which affects career decision making processes (Palazzeschi, Levin, \& Gati, 2015). It is also described as the extent to which someone succeeds in completing particular tasks and performing actions in the process of career decision making, such as self-assessment, job information collection, goals determination, future plan, and problem solving (Betz \& Luzzo, 1996). In addition to this, Junior High School students should know how to do career decision making. Taylor \& Bertz (1983) state that CDSE-SF is important to one's career decision making. It covers several cognitive outcomes and career behavior aspects, such as career determination, career decision making, career optimism, career commitment, and many others. Bandura's theory states that career decision self-efficacy is the main mediator for behavior direction and behavior change direction (Betz, Hammond, \& Multon, 2005). Selfefficacy of career decisions has become a theoretical and empirical concern, as well as its role in predicting a person's behavior or the direction of choosing a person's behavior (Song \& Chon, 2012). Pambudi, Mulawarman, \& Japar (2016) proved that students have a high level of self-efficacy, can do good career planning.

Work fields are increasingly differentiated or specified, so applicants should have higher abilities to get a job. The transition of school level to university or higher education level is one important step to pursue career success in the future, while career planning failure may be influenced by current decision making (Koen, Klehe, \& Vianen, 2012; Savickas, 2012; Nilforooshan \& Salimi , 2016). Unfortunately, in reality, there found many High School students feeling confused about career decision making, meaning that not all students are able to make the right decision. It is in line with data collected from a case study regarding the stability of career decision making by the eighth grade students of Sudirman Ambawara Islamic Middle School that the students had low career maturity qualifications (Purnamasari, 2015). Another finding from Ragasukmasuci (2013) who investigated the ninth grade students in Public Junior High School 9 Bandung indicated that $79 \%$ of students were confused about choosing High School, $71 \%$ of students have not yet been able to solve their own problems when choosing school to continue their study, and $72 \%$ of students were not courage to express their ideas about school to choose. Also, a study by Malichah (2014) revealed that the students of Public Junior High School 3 Prambanan felt hesitant in decision making and most of them have not yet made a choice after graduating from their Junior High School. Similarly, Iskandar's study (2015) which investigated career guidance programs designed based on the career decision of the ninth grade students of Public Junior High School for Islamic Education 2 Bandung concluded that students were confused and still influenced by parents or their peers so that the career they decided was not originally based on their interest. Edwards \& Quinter (2011) proved that junior high school students did not know accurate career information which resulted in low knowledge of career opportunities.

Given the burden of the above problems, there were some problems arouse, such as how to prepare for the future, kinds of education to take to obtain the expected job or career, and 
how to get that job or career. These situations become problems faced by students in planning their career. Also, these may arise due to lack of information, such as requirements and professional interests needed to achieve a particular career. Therefore, students need to have sufficient information on their future school to help them make a choice.

\section{Rationale of the Current Study}

After previously making a survey, obtaining information regarding students' problems in career, and reviewing some studies related to career decision making self-efficacy, students' career understanding on career decision making self-efficacy became the focus of this study. To do so, the researchers employed Career decision making self-efficacy (CDSESF) (Betz \& Klein, 1996) as the main instrument in measuring the level of self-efficacy in career decision making with indicators that include 1) Self-appraisal, 2) Occupational information, 3) Goal selection, 4) Making plans for the future, and 5) Problem solving.

\section{Objective}

Since there found a study limited to Junior High School career understanding, the current study focused on investigating the difference in self-efficacy and the career decision making of Junior High School who have and have not gained career understanding knowledge.

\section{METHODS}

\section{Participants}

The participants in this study were Junior High School students in Central Java Province, while the sample was representative residency chosen randomly and resulted 311 respondents. To obtain their data, the researchers used an adopted instrument that has been back-translated into Indonesian. For more, students' career decision self-efficacy was measured using an adopted instrument of career decision making self-efficacy (CDSE-SF) (Betz \& Klein, 1996) and questionnaire of students' career understanding.

\section{Instruments}

Following instruments were used to access study constructs.

\section{Career understanding questionnaire}

Career understanding questionnaire consists of 4 aspects, namely 1) understanding of various job alternatives, 2) Information on the world of work requirements, 3) Information on job vacancies, and 4) Understanding of job qualifications. This closed questionnaire was aimed at sorting out students who have and have not admitted that they have career understanding.

\section{Career decision making self-efficacy (CDSE-SF)}

CDSE-SF consists of 25 items and was developed from 5 indicators, namely 1) Selfappraisal, 2) Occupational information, 3) Goal selection, 4) Making plans for the future, and 5) Problem solving. The scale value was interpreted using Likert scale, covering 1 (not sure) to 5 (strongly sure). The higher score students obtained, the higher their career decision making self-efficacy would be. Further, this instrument got a reliability value of .786 Cronbach Alpha that was designed and developed by Betz, Klein, \& Taylor (1996).

\section{Procedures}

This study began with contacting schools and asking for permission to involve students to participate. Once the approval was obtained, the researchers came to the class on the agreed 
Table 1. CDSE-SF test results among students who have understood various job alternatives

\begin{tabular}{llllll}
\hline Variable & $\begin{array}{l}\text { Groups } \\
\text { (Understanding) }\end{array}$ & $\mathrm{N}$ & $\mathrm{SD}$ & $\mathrm{t}$ & $\mathrm{p}$ \\
\hline Self-Appraisal & Yes & 258 & 2.49696 & 5.367 & .000 \\
& No & 53 & 4.20096 & & \\
Occupational Information & Yes & 258 & 5.37172 & 5.077 & .000 \\
& No & 53 & 5.75144 & & \\
Goal Selection & Yes & 258 & 3.39264 & 3.920 & .000 \\
\multirow{2}{*}{ Making Plans for The Future } & No & 53 & 5.02786 & & \\
& Yes & 258 & 3.44358 & 4.350 & .000 \\
Problem Solving & No & 53 & 4.95890 & & \\
\multirow{2}{*}{ CDMSE } & Yes & 258 & 3.42155 & 3.922 & .000 \\
& No & 53 & 4.80233 & & \\
& Yes & 258 & 14.92982 & 4.911 & .000 \\
\hline
\end{tabular}

Table 2. CDSE-SF test results among students who have understood various information requirements of the world of work

\begin{tabular}{llllll}
\hline Variable & $\begin{array}{l}\text { Groups } \\
\text { (Understanding) }\end{array}$ & $\mathrm{N}$ & $\mathrm{SD}$ & $\mathrm{t}$ & $\mathrm{p}$ \\
\hline Self-Appraisal & Yes & 239 & 2.52161 & 4.590 & .000 \\
& No & 72 & 4.04704 & & \\
Occupational Information & Yes & 239 & 5.39252 & 4.571 & .000 \\
& No & 72 & 5.77999 & & \\
Goal Selection & Yes & 239 & 3.37849 & 4.350 & .000 \\
& No & 72 & 4.66096 & & \\
Making Plans for The Future & Yes & 239 & 3.37337 & 4.203 & .000 \\
Problem Solving & No & 72 & 4.85752 & & \\
& Yes & 239 & 3.45222 & 2.860 & .005 \\
CDMSE & No & 72 & 4.65391 & & \\
& Yes & 239 & 15.04450 & 4.602 & .000 \\
\hline
\end{tabular}

date, distributed informed consent forms to students, and asked for students' willingness to participate in this survey. After the participants accepted the questionnaire and letter telling the objectives of the study, they were asked to fill the questionnaire and handed in to the researchers for its confidentiality. After that, the data were analyzed using t-test.

\section{RESULTS AND DISCUSSION}

\section{Results}

The data of this study were collected through the career decision self-efficacy scale that has been filled by 311 students. The results were categorized into two, namely the students who have and have not gained knowledge about career understanding including 1) understanding of various job alternatives, 2) Information on the world of work requirements, 3) Information on job vacancies, and 4) Understanding of job qualifications.

Students' differences in career understanding was determined using t-test. In terms of various job alternatives understanding, the researcher gained the score of $(\mathrm{t}(311)=4.911, \mathrm{p}<$ .000) covering all aspects of CDSE-SF 1) Self-Appraisal, 2) Occupational Information, 3) Goal Selection, 4). Making Plans for the Future, and 5) Problem Solving. The details can be seen in table 1.

CDSE-SF test results showed differences between students who have and have not understood information on the world of work requirements indicated by the value of t-test. 
Table 3. CDSE-SF test results among students who have understood information on job vacancies

\begin{tabular}{llllll}
\hline Variable & $\begin{array}{l}\text { Groups } \\
\text { (Understanding) }\end{array}$ & $\mathrm{N}$ & $\mathrm{SD}$ & $\mathrm{t}$ & $\mathrm{p}$ \\
\hline Self-Appraisal & Yes & 238 & 2.66677 & 3.311 & .001 \\
& No & 73 & 3.97251 & & \\
Occupational Information & Yes & 238 & 5.55931 & 4.017 & .000 \\
& No & 73 & 5.47472 & & \\
Goal Selection & Yes & 238 & 3.54391 & 4.640 & .000 \\
& No & 73 & 4.23240 & & \\
Making Plans for The Future & Yes & 238 & 3.52762 & 3.523 & .001 \\
Problem Solving & No & 73 & 4.65372 & & \\
& Yes & 238 & 3.46499 & 2.729 & .008 \\
CDMSE & No & 73 & 4.63114 & & \\
& Yes & 238 & 15.79957 & 4.111 & .000 \\
\hline
\end{tabular}

Table 4. CDSE-SF test results among students who have understood job qualifications

\begin{tabular}{llllll}
\hline Variable & $\begin{array}{l}\text { Groups } \\
\text { (Understanding) }\end{array}$ & $\mathrm{N}$ & $\mathrm{SD}$ & $\mathrm{t}$ & $\mathrm{p}$ \\
\hline Self-Appraisal & Yes & 167 & 2.72967 & 3.656 & .000 \\
& No & 144 & 3.35401 & & \\
Occupational Information & Yes & 167 & 4.20492 & 2.306 & .022 \\
& No & 144 & 6.92338 & & \\
Goal Selection & Yes & 167 & 3.49091 & 3.607 & .000 \\
Making Plan for The Future & No & 144 & 4.10596 & & \\
\multirow{2}{*}{ Problem Solving } & Yes & 167 & 3.43942 & 3.403 & .001 \\
& No & 144 & 4.27212 & & \\
CDMSE & Yes & 167 & 3.57863 & 2.419 & .016 \\
& No & 144 & 4.02901 & & \\
& Yes & 167 & 15.13645 & 3.460 & .001 \\
\hline
\end{tabular}

The differences were found significant by having the score of $(\mathrm{t}(311)=4.602, \mathrm{p}<.000)$, covering all aspects of CDSE-SF 1) Self-Appraisal, 2) Occupational Information, 3) Goal Selection, 4) Making a Plan for the Future, and 5) Problem Solving. The table 2 presents the data in detail.

CDSE-SF test results showed differences between students who have and have not understood information on job vacancies indicated by the value of t-test. The differences were found significant by having the score of $(\mathrm{t}(311)=4.111, \mathrm{p}<.000)$, covering all aspects of CDSE-SF 1) Self-Appraisal, 2) Occupational Information, 3) Goal Selection, 4) Making a Plan for the Future, and 5) Problem Solving. The table 3 presents the data in detail.

Furthermore, CDSE-SF test results showed differences between students who have and have not understood of job qualifications indicated by the value of t-test. The differences were found significant by having the score of $(\mathrm{t}(311)=3.460, \mathrm{p}<.001)$, covering all aspects of CDSE-SF: 1) Self-Appraisal, 2) Occupational Information, 3) Goal Selection, 4) Making a Plan for the Future, and 5) Problem Solving. The table 4 presents the data in detail.

\section{Discussion}

According to the findings of this study, the researchers revealed that Junior High School students' career understanding was strongly influenced by career selection self-efficacy. Also, 
some differences in the students' career decision making were discovered through CDSE-SF test in terms of career understanding in the world of work, covering: 1) Understanding of various job alternatives, 2) Information on the world of work requirements, 3) Information on job vacancies, and 4) Understanding of job qualifications. Taylor \& Betz (1983) define career decision self-efficacy as one's belief in understanding and assessing himself appropriately, finding jobs information sources, determining career goals, making career plans, and solving problems related to career directions.

The findings are supported by Winkel \& Hartini (2018) that career understanding helps people develop unity and self-image as well as their roles in the world of work. That is why good career understanding is in line with career decision making self-efficacy. Kebudayaan (2013) state that the developmental tasks of Indonesian adolescents, including Junior High School students are to recognize abilities, talents, interests, career trend direction and artistic appreciation, and develop knowledge and skills based on their needs to follow and continue what they study or prepare career and play roles in daily life.

Adolescents in high school are demanded to determine their career after graduating from Junior High School. Apart from career, they are also faced with jobs choices, further education, and productive activities (Pascual, 2014). To choose one of these choices is the realization of adolescents' decision after considering their potential, weaknesses, information on the fields of work they are going to take, and risks to take after deciding career plans during their study in Junior High School. Regarding the findings, several Guidance and Counseling services can be provided as long as the services can improve understanding of various jobs alternatives, information on the world of work requirements, information of job vacancies, and understanding of various works qualifications. The more complete and thorough the information, the easier it is for individuals to make choices and decision for their career (Robbins, 2003).

Brown and Lent (2005) argue that interventions in the process of career development, such as individual career counselling, group career counselling, classroom-based career curriculum, and career education are effective to assist and direct children and adolescents' career. Besides, trainings are also useful for individual career planning in terms of improving the direction in the choice of career interest fields (Purnamasari, 2015). Career planning training provides understanding that builds students' awareness of their potential and limitations, understanding of various career opportunities alternatives and skills in determining career choices (Damayanti \& Widyowati, 2018).

\section{Limitations and Suggestions}

However, apart from the advantages the findings provide, the researchers certainly realize some limitation - for example, there is a need to further examine the relationship between career understanding and career decision self-efficacy, particularly in terms of individual cultural factors.

\section{Implications}

These findings imply that individual career understanding strongly influences career decision making self-efficacy, particularly for Junior High School students. Therefore, the provision of guidance and counseling services in Junior High School are supposed to be directed towards the improvement of students' career understanding. By doing so, students' career decision self-efficacy will gain some encouragement.

\section{CONCLUSIONS}

This study aimed to analyze the career decision making self-efficacy of Junior High School students through career understanding. Based on the findings, it can be concluded that 
there are significant differences in students who stated that they have gained career understanding and students who have not gained career decision making self-efficacy understanding. Apart from the findings, this study has some limitation regarding the sample collection that can be expanded to other provinces with diverse cultural background. Therefore, the future studies are suggested to provide career guidance services with many different innovations as an independent variable.

\section{ACKNOWLEDGEMENTS}

The authors sincere their grateful to the Ministry of Research, Technology, and Higher Education of Republic of Indonesia which has funded the this research in 2020.

\section{AUTHOR CONTRIBUTIONS STATEMENT}

KNA and TB have conducted preliminary studies, prepared research designs, collected data at the study site and analyzed the data. DYP and MJ have provided guidance, instructions, criticisms, and advice in the preparation of research designs and supervision during the research process.

\section{REFERENCES}

Bandura, A. (1969). Social-Learning Theory of Identificatory Processes. Handbook of Socialization Theory and Research. United States of America: Stanford University. https://doi.org/10.1080/19371918.2011.591629

Bandura, A. (1989). Social Cognitive Theory: An Agentic Perspective. In Annual Review of Psychology (Vol. 6, pp. 1-60). https://doi.org/10.1146/annurev.psych.52.1.1

Bandura, A. (2009). Cultivate Self - efficacy for Personal and Organizational Efectiveness. Handbook of Principles of Organizational Behavior, 179-200. https://doi.org/10.1111/b.9780631215066.2003.00010

Betz, N. E., \& Luzzo, D. A. (1996). Career assessment and the career decisionmaking selfefficacy scale. Journal of Career Assessment, 4(4), 413-428. https://doi.apa.org/doi/10.1037/0022-0167.43.1.90

Betz, N. E., Hammond, M. S., \& Multon, K. D. (2005). Reliability and Validity of Five-Level Response Continua for the Career Decision Self-Efficacy Scale. Journal of Career Assessment, 13(2), 131-149. https://doi.org/10.1177/1069072704273123

Betz, N. E., Klein, K. L., \& Taylor, K. M. (1996). Evaluation of A Short Form of the Career Decision-Making Self-Efficacy Scale. Journal of Career Assessment, 4(1), 47-57. https://doi.org/10.1177/106907279600400103

Brown, S. D., \& Lent, R. W. (2005). Career development and counseling: Putting theory and research to work. John Wiley \& Sons, Inc. Retrieved from Google Scholar

Damayanti, D., \& Widyowati, A. (2018). Peningkatan Career Decison Making Self Efficacy (CDMSE) melalui Pelatihan Perencanaan Karir pada Siswa SMK. Humanitas: Jurnal Psikologi Indonesia, 15(1), 35-45. https://doi.org/10.26555/humanitas.v15i1.7409

Depdiknas. (2003). Undang-undang RI No. 20 tahun 2003 Tentang Sistem Pendidikan Nasional. Retrieved from Google Scholar

Edwards, K., \& Quinter, M. (2011). Factors Influencing Students Career Choices among Secondary School students in Kisumu Municipality, Kenya. Journal of Emerging Trends in Educational Research and Policy Studies (JETERAPS), 2(2), 81-87. https://hdl.handle.net/10520/EJC135714

Malichah, F. (2014). Pelaksanaan Bimbingan Kelompok Dalam Upaya Penentuan Pengambilan Keputusan Studi Lanjut Pada Siswa Kelas IX Di SMPN 3 Prambanan Yogyakarta (Thesis UIN Sunan Kalijaga Yogyakarta). Retrieved from Google Scholar 
Iskandar, P. A. (2015). Program Bimbingan Karier Berdasarkan Profil Keputusan Karier Peserta Didik : Penelitian Deskriptif Terhadap Peserta Didik Kelas IX Mts Negeri 2 Bandung Tahun Ajaran 2014/2015 (Thesis UPI Bandung). Retrieved from Google Scholar

Kebudayaan, K. P. (2013). Pedoman Penelusuran Minat Peserta Didik Sekolah Menengah Pertama. Jakarta: Direktorat Jenderal Pendidikan Dasar Kementerian Pendidikan dan Kebudayaan. Retrieved from Google Scholar

Kebudayaan, K. P. (2016). Panduan Operasional Penyelenggaraan Bimbingan dan Konseling Sekolah Menengah Pertama. Retrieved from Google Scholar

Koen, J., Klehe, U. C., \& Van Vianen, A. E. (2012). Training career adaptability to facilitate a successful school-to-work transition. Journal of Vocational Behavior, 81(3), 395-408. https://doi.org/10.1016/j.jvb.2012.10.003

Pascual, T. N. (2014). Factors Affecting High School Students' Career Preference: A Basis for Career Planning Program. International Journal of Sciences: Basic and Applied Research, 16(1), 1-14. Retrieved from Google Scholar

Nilforooshan, P., \& Salimi, S. (2016). Career Adaptability as A Mediator Between Personality and Career Engagement. Journal of Vocational Behavior, 94, 1-10. https://doi.org/10.1016/j.jvb.2016.02.010

Palazzeschi, L., Levin, N., Levin, N., \& Gati, I. (2015). The role of personality in the career decision-making difficulties of italian young adults. Journal of Career Assessment, 23(2), 281-293. https://doi.org/10.1177/1069072714535031

Purnamasari. D. S. S. P. (2015). Tingkat Kematangan Karir Siswa Kelas VIII SMP Islam Sudirman Ambarawa. Widya Sari, 17(2), 1-7. Retrieved from Google Scholar

Ragasukmasuci, L. B. (2013). Program Bimbingan Karier untuk Meningkatkan Kemampuan Pembuatan Keputusan Karier Peserta Didik Sekolah Menengah Pertama (Thesis UPI Bandung). Retrieved from Google Scholar

Robbins, S. P. (2003). Perilaku organisasi: konsep kontroversi aplikasi. edisi kedelapan. Trans. Pujaatmaka, $H$ \& Molan, B. Jakarta: PT. Prenlindo. Retrieved from Google Scholar

Savickas, M. L. (2012). Life Design: A Paradigm for Career Intervention in the 21st Century. Journal of Counseling \& Development, 90(1), 13-19. https://doi.org/10.1111/j.15566676.2012.00002.x

Song, Z., \& Chon, K. (2012). General Self-Efficacy's Effect On Career Choice Goals Via Vocational Interests and person-Job Fit: A mediation model. International Journal of Hospitality Management, 31(3), 798-808. https://doi.org/10.1016/j.ijhm.2011.09.016

Steinberg, L. (2014). Adolescence (Tenth Edition). New York: McGraw-Hill. Retrieved from Google Scholar

Breeding, R. R. (2008). Empowerment as a function of contextual self-understanding: The effect of work interest profiling on career decision self-efficacy and work locus of control. Rehabilitation Counseling Bulletin, 51(2), 96-106. https://doi.org/10.1177/0034355207311346

Taylor, K. M., \& Betz, N. E. (1983). Applications Of Self Efficacy Theory To The Understanding and Treatment Of Career Indecision. Journal of Vocational Behavior, 22, 63-81. https://doi.org/10.1016/0001-8791(83)90006-4

Pambudi, A. T., Mulawarman, M., \& Japar, M. (2019). Psychoeducational group with modelling technique to improve career adaptability through career decision selfefficacy. Jurnal Bimbingan $\quad$ Konseling, 8(1), 20 . https://doi.org/10.15294/jubk.v8i1.26617

Winkel, W. S., \& Hastuti, M. S. (2005). Bimbingan Konseling Di Instusi Pendidikan. Yogyakarta: Media abadi. Retrieved from Google Scholar 
Students' Career Understanding and Career Decision Making Self-Efficacy in Junior High School

Copyright holder :

(C) Akhsania, K., Basuki, T., Sugiharto, D., \& Japar, M. (2021)

First publication right :

Islamic Guidance and Counseling Journal

This article is licensed under:

\section{CC-BY-SA}

